\section{Commentary: The molecular pandemonium of coronavirus disease 2019}

\author{
Leora B. Balsam, MD, ${ }^{\mathrm{a}}$ and \\ William D. Hoffman, MD ${ }^{\mathrm{b}}$
}

The coronavirus disease 2019 (COVID-19) global pandemic has widely influenced healthcare delivery and disrupted daily life across the globe. In our surgical practices, elective schedules have been canceled and patients who normally would be presenting to hospitals are avoiding or delaying care due to fear of exposure to the virus. During the past 3 months, our own institution has seen a decline in patients presenting with acute coronary syndromes, and similar experiences were summarized in The New York Times article "Where have all the heart attacks gone?"1 At the same time, we've personally seen a marked increase in late presentations of ST-elevation myocardial infarction, with 2 cases of ventricular septal rupture during the past 6 weeks. Hospitals have been inundated with COVID-19 patients and clinicians have found themselves on a steep learning curve with a new disease. COVID-19 is of particular interest to cardiothoracic surgeons because of its effects on both the respiratory and cardiovascular systems. Although the predominant illness is respiratory, cardiovascular complications such as arrhythmias, myocarditis, pericarditis, and heart failure can occur in more severe cases. Additionally, COVID-19 patients with cardiovascular comorbidities are more likely to develop symptomatic infections and are also more likely to die of the disease. ${ }^{2}$

The interplay between the virus that causes COVID-19, severe acute respiratory syndrome coronavirus 2 (SARS$\mathrm{CoV}-2$ ), and the cardiovascular system is the subject of a review by Thankam and Agrawal in the Journal. ${ }^{3}$ This single-

\footnotetext{
From the ${ }^{\mathrm{a} D i v i s i o n}$ of Cardiac Surgery and ${ }^{\mathrm{b}}$ Department of Anesthesiology and Perioperative Medicine, UMass Memorial Medical Center, Worcester, Mass.

Disclosures: The authors reported no conflicts of interest.

The Journal policy requires editors and reviewers to disclose conflicts of interest and to decline handling or reviewing manuscripts for which they may have a conflict of interest. The editors and reviewers of this article have no conflicts of interest.

Received for publication June 2, 2020; revisions received June 2, 2020; accepted for publication June 2, 2020; available ahead of print June 6, 2020.

Address for reprints: Leora B. Balsam, MD, Division of Cardiac Surgery, UMass Memorial Medical Center, University Campus, 55 Lake Ave N, Worcester, MA 01655 (E-mail: leora.balsam@umassmemorial.org).

J Thorac Cardiovasc Surg 2021;161:e227-8

$0022-5223 / \$ 36.00$

Copyright (C) 2020 by The American Association for Thoracic Surgery

https://doi.org/10.1016/j.jtcvs.2020.06.003
}

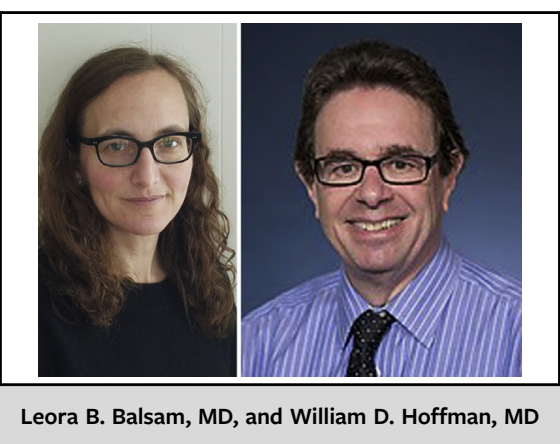

\author{
CENTRAL MESSAGE \\ COVID-19 and cardiovascular \\ disease are linked. Knowledge of \\ the basic science will help us \\ understand why this link exists \\ and how to best treat infected \\ patients with cardiovascular \\ comorbidities.
}

stranded RNA virus shares more than $80 \%$ sequence homology with SARS-CoV, which caused the 2003 SARS outbreak, and engages the same target receptor on the cell surface, angiotensin-converting enzyme 2 (ACE2). After binding ACE2, the virus is internalized and begins replicating. The host cell's endoplasmic reticulum and Golgi apparatus are utilized to package the viral particles. Under normal conditions, ACE2 plays an important role in balancing activities of the renin angiotensin system, with a vasodilatory effect. With COVID-19 infection, ACE2 is downregulated, promoting vasoconstriction. The authors propose that this may be particularly harmful in patients with cardiovascular comorbidities.

The authors also discuss the influence of the widely used neurohormonal blocking agents, ACE inhibitors, and angiotensin receptor-blocking agents on COVID-19 infection. On the one hand, there is considerable evidence that these agents have a protective effect on patients with heart failure and/or hypertension by inhibiting the renin angiotensin system. On the other hand, animal studies have shown that these drugs upregulate the expression of ACE2, the protein that facilitates viral entry into the host cell. Current consensus from the American Hospital Association/American College of Cardiology/Heart Failure Society of America and European Society of Cardiology is that we should continue to use these medications in patients when clinically indicated though more research is warranted. 
The authors describe molecular pathways involved in the immune response to COVID-19, focusing on the cytokine response. In some patients, this inflammatory response results in cardiac injury, as manifested by elevated levels of circulating cardiac biomarkers. Troponin release in COVID19 patients with underlying cardiovascular risk factors has been shown to be highly predictive of requirement for intensive care unit admission, mechanical ventilation, and death. ${ }^{4}$ Although the cytokine response is the host's ammunition against the virus, the inflammatory response that ensues may result in collateral damage to host tissues and organs.

Understanding the molecular pathways involved in COVID-19 pathogenesis is critical for the development of diagnostic and therapeutic tools. As the authors explain, the virus has been sequenced and its nonstructural and structural proteins have been described. Some of these will likely be targets for a vaccine in the future. Yet with more than 6 million confirmed cases and 370,000 deaths as of June 1, $2020,{ }^{5}$ we remain in dire need of therapeutics for the disease. It is likely that insight into the basic science of COVID-19 will translate into treatment options in the future.

\section{References}

1. Krumholz H. Where have all the heart attacks gone? The New York Times. April 6, 2020.

2. Bonow RO, Fonarow GC, O' Gara PT, Yancy CW. Association of coronavirus disease 2019 (COVID-19) with myocardial injury and mortality. JAMA Cardiol. March 27, 2020 [Epub ahead of print].

3. Thankam FG, Agrawal DK. Molecular chronicles of cytokine burst in patients with coronavirus disease 2019 (COVID-19) with cardiovascular diseases. J Thorac Cardiovasc Surg. 2021;161:e217-26.

4. Guo T, Fan Y, Chen M, Wu X, Zhang L, He T, et al. Cardiovascular implications of fatal outcomes of patients with coronavirus disease 2019 (COVID-19). JAMA Cardiol. March 27, 2020 [Epub ahead of print].

5. World Health Organization coronavirus disease 2019 (COVID-19) dashboard. Available at: https://covid19.who.int/. Accessed June 1, 2020.
See Article on page e217.

\section{Commentary: Evolving understanding of coronavirus disease 2019: Molecular biology, immunology, and surgery}

\author{
Edward Buratto, MBBS, $\mathrm{PhD},{ }^{\mathrm{a}, \mathrm{b}, \mathrm{c}}$ and \\ Igor E. Konstantinov, MD, PhD, FRACS ${ }^{\mathrm{a}, \mathrm{b}, \mathrm{c}, \mathrm{d}}$
}

The global pandemic of coronavirus disease 2019 (COVID19) has major implications for cardiothoracic surgeons. It

\footnotetext{
From the ${ }^{\text {a}}$ Department of Cardiac Surgery, Royal Children's Hospital, Melbourne Australia; 'bepartment of Paediatrics, University of Melbourne, Melbourne,

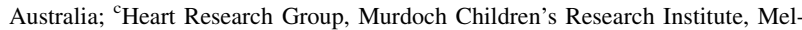
bourne, Australia; and ${ }^{\mathrm{d}}$ Melbourne Centre for Cardiovascular Genomics and Regenerative Medicine, Melbourne, Australia.

Disclosures: The authors reported no conflicts of interest.

The Journal policy requires editors and reviewers to disclose conflicts of interest and to decline handling or reviewing manuscripts for which they may have a conflict of interest. The editors and reviewers of this article have no conflicts of interest.

Received for publication May 28, 2020; revisions received May 28, 2020; accepted for publication May 28, 2020; available ahead of print June 6, 2020.

Address for reprints: Igor E. Konstantinov, MD, PhD, FRACS, Department of Cardiac Surgery, Royal Children's Hospital, Flemington Rd, Parkville, 3052, Australia (E-mail: igor.konstantinov@ @rch.org.au).

J Thorac Cardiovasc Surg 2021;161:e228-30 0022-5223/\$36.00

Crown Copyright $(2020$ Published by Elsevier Inc. on behalf of The American Association for Thoracic Surgery

https://doi.org/10.1016/j.jtcvs.2020.05.087
}

Check for updates

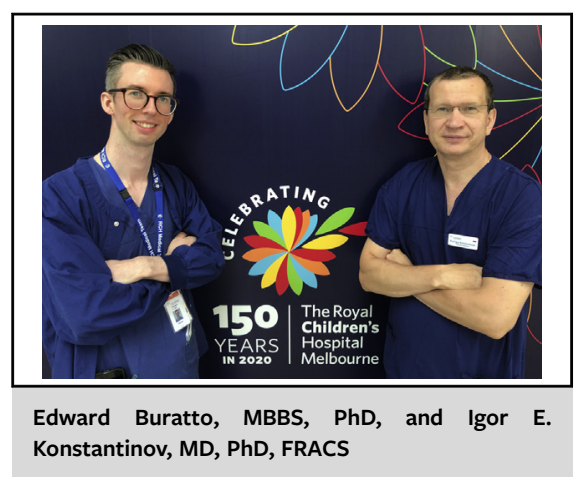

CENTRAL MESSAGE

Understanding molecular mechanisms of COVID-19 disease is crucial for cardiothoracic surgeons.

has influenced all aspects of our lives. Resources that previously seemed unlimited have become scarce. The COVID-19 pandemic has not only resulted in dramatically increased need for urgent mechanical cardiorespiratory support in the epicentres of disease outbreaks but also put significant pressure on perioperative management of patients-ranging from congenital heart disease to organ 